\title{
Molecular Genetic Characterization of Sweet potato virus $G$ (SPVG) Isolates from Areas of the Pacific Ocean and Southern Africa
}

M. Rännäli and V. Czekaj, Department of Applied Biology, P.O. Box 27, FIN-00014 University of Helsinki, Finland; R. A. C. Jones, Agricultural Research Western Australia, Locked Bag No. 4, Bentley Delivery Centre, Perth, WA 6983, and WA State Agricultural Biotechnology Centre, Murdoch University, Perth, WA 6150, Australia; J. D. Fletcher, New Zealand Institute for Crop \& Food Research, Private Bag 4704, Christchurch, New Zealand; R. I. Davis, Northern Australia Quarantine Strategy (NAQS) and Australian Quarantine and Inspection Service (AQIS), P.O. Box 1054, Mareeba, Queensland 4880, Australia; L. Mu, Service du Dévelopement Rural, Département de la Protection des Végétaux, BP 100, Papeete, French Polynesia; G. I. Dwyer and B. A. Coutts, Agricultural Research Western Australia, Locked Bag No. 4, Bentley Delivery Centre, Perth, WA 6983, Australia; and J. P. T. Valkonen, Department of Applied Biology, P.O. Box 27, FIN-00014 University of Helsinki, Finland

\begin{abstract}
ABTRACT
Rännäli, M., Czekaj, V., Jones, R. A. C., Fletcher, J. D., Davis, R. I., Mu, L., Dwyer, G. I., Coutts, B. A., and Valkonen, J. P. T. 2008. Molecular genetic characterization of Sweet potato virus $G$ (SPVG) isolates from areas of the Pacific Ocean and southern Africa. Plant Dis. 92:1313-1320.

Sweet potato virus $G$ (SPVG, genus Potyvirus, family Potyviridae) was detected in sweetpotato (Ipomoea batatas) storage roots sold in the local markets and storage roots or cuttings sampled directly from farmers' fields. Using serological and molecular methods, the virus was detected for the first time in Java, New Zealand, Hawaii, Tahiti, Tubuai, Easter Island, Zimbabwe, and South Africa, and also in an imported storage root under post-entry quarantine conditions in Western Australia. In some specimens, SPVG was detected in mixed infection with Sweet potato feathery mottle virus (genus Potyvirus). The coat protein (CP) encoding sequences of SPVG were analyzed for 11 plants from each of the aforementioned locations and compared with the $\mathrm{CP}$ sequences of 12 previously characterized isolates from China, Egypt, Ethiopia, Spain, Peru, and the continental United States. The nucleotide sequence identities of all SPVG isolates ranged from 79 to $100 \%$, and amino acid identities ranged from 89 to $100 \%$. Isolates of the same strain of SPVG had nucleotide and amino acid sequence identities from 97 to $100 \%$ and 96 to $100 \%$, respectively, and were found in sweetpotatoes from all countries sampled except Peru. Furthermore, a plant from Zimbabwe was co-infected with two clearly different SPVG isolates of this strain. In contrast, three previously characterized isolates from China and Peru were phylogenetically distinct and exhibited $<90 \%$ nucleotide identity with any other isolate. So far, the highest genetic diversity of SPVG seems to occur among isolates in China. Distribution of SPVG within many sweetpotato growing areas of the world emphasizes the need to determine the economic importance of SPVG.
\end{abstract}

Sweetpotato (Ipomoea batatas Lam.) is the third most important root crop globally after potato and cassava. It is grown in all subtropical and tropical climatic regions of the world (15). Based on genetic diversity studies, the center of origin of sweetpotato is believed to be Mexico and Central America (42), although the oldest indications of cultivated sweetpotatoes come from Peru (32). In the islands of the Pacific Ocean, long before the arrival of European colonizers, sweetpotatoes were widely grown by Polynesian inhabitants. The oldest archeological records of sweetpotato in this region are from the Cook Islands of

Corresponding author: J. P. T. Valkonen

E-mail: jari.valkonen@ helsinki.fi

Accepted for publication 16 May 2008.

doi:10.1094/PDIS-92-9-1313

(C) 2008 The American Phytopathological Society
Central Polynesia (A.D. 1000 to 1100), Hawaii (A.D. 1290 to 1430), and Easter Island (ca. A.D. 1500) (32). Central Polynesia (Tuamotu, Marquesas, and Society islands) may be the likely area of original arrival of sweetpotatoes in Oceania coming from the coast of Ecuador, Peru, or northern Chile $(10,32)$. In Australasia, sweetpotatoes were first introduced to New Zealand about 800 years ago by Maori settlers from Polynesia. Before European colonization, the crop (known as kumara) was cultivated widely by the Maoris as a staple carbohydrate food source. Although its use declined following the introduction of alternative staple carbohydrate crops, such as potato and maize (29), it is still regarded as an important crop there with 1,400 ha grown annually. In Australia, sweetpotatoes were introduced less than 200 years ago following European colonization, although Australian aboriginals apparently had harvested native yams (I. polpha and $I$. costata) for millennia. Sweetpotatoes were possibly introduced to the Philippines and India by Spanish voyagers in the sixteenth century (10), but it seems unlikely that these were the first introductions to these locations.

Viruses are the most serious pathogens limiting sweetpotato production worldwide (30), but relatively little is known about the occurrence of viruses in sweetpotatoes grown in Oceania. Sweet potato caulimolike virus (SPCaLV; genus Caulimovirus, family Caulimoviridae) has been detected in sweetpotato samples from Papua New Guinea, Solomon Islands, Tonga, New Zealand, and Australia, and Sweet potato ringspot virus (SPRSV; a putative member of the genus Nepovirus) from Papua New Guinea $(5,7)$. Detections of Sweet potato feathery mottle virus (SPFMV; genus Potyvirus, family Potyviridae) in Fiji, Tonga, and the Solomon Islands are included in the listing of Pearson and Grisoni (34). Fletcher et al. (16) surveyed sweetpotato crops in the Kaipara district of Northland, which produces $80 \%$ of the crop in New Zealand. Their serological tests detected the three potyviruses SPFMV, Sweet potato latent virus, and the $\mathrm{C} 8$ virus that was later named Sweet potato mild speckling virus (41); Sweet potato mild mottle virus (genus Ipomovirus, family Potyviridae), Sweet potato chlorotic fleck virus (SPCFV), and $\mathrm{C6}$ virus, another putative member of the genus Carlavirus (Flexiviridae) (41); Cucumber mosaic virus (genus Cucumovirus, family Bromoviridae) and SPCaLV. Studies of viruses in sweetpotatoes in Australia have revealed the occurrence of SPFMV (17,20,22,37,39), Sweet potato virus 2 (SPV2, genus Potyvirus) (37), and SPCFV (22). According to Salazar and Fuentes (35), most of these and many other viruses have been detected in Indonesia, the Philippines, and Papua New Guinea, but the original reports and details of detection methods were not cited.

The species Sweet potato virus $G$ (SPVG) is a member of genus Potyvirus that has gained relatively little attention so far. It was originally described from China $(11,12)$ and is also known to occur in the 
United States (36). In Africa, SPVG has been detected in sweetpotatoes grown in Egypt (21) and Ethiopia (1), whereas extensive surveys of sweetpotato viruses in the Lake Victoria basin in East Africa and northern parts of South Africa have not detected it $(2-4,33,38)$. The goal of this study was to survey sweetpotatoes grown in Oceania for SPVG and to assess the genetic diversity of the virus. Samples were collected from Java, Hawaii, French Polynesia, New Zealand, and Easter Island. In addition, a few samples of sweetpotato were collected from Zimbabwe and the southernmost part of South Africa. The results revealed that SPVG is geographically much more widely distributed in the world than previously realized and that many isolates from geographically distant locations were identical.

\section{MATERIALS AND METHODS}

Plant material. Storage roots of an unknown, purple-skinned landrace of sweetpotato were collected from a commercial planting at Toahotu, in the south of the island of Tahiti, French Polynesia, in September 2004. Similarly, an unnamed purple-skinned landrace was sampled in Mataura on the island of Tubuai that also belongs to French Polynesia, in October 2004. From New Zealand, cuttings from eight sweetpotato cultivars or landraces growing in home gardens in Dargaville in Northland were sampled in November-
December 2004. One of these was cv. Owairaka Red that dominates the sweetpotato industry in New Zealand. It is a selected red-skinned, cream-fleshed mutant of a local 'Waina' landrace introduced from Rarotonga in the 1850s (29). On Easter Island, storage roots of four cultivars or landraces of sweetpotato with different skin colors and shapes were purchased from an open farmers' market at Hanga Roa in March 2005.

Samples from South Africa and Zimbabwe were obtained in April 2005. Two batches of storage roots of the red-skinned local cultivar Borie were purchased separately at a vegetable stall and in a supermarket in Capetown, South Africa. In Zimbabwe, storage roots of two cultivars, one white skinned (Chena) and the other red skinned (Tsvuku), were dug in a field close to Victoria Falls airport. More storage roots of cv. Chena were obtained from a field in Mukhosana nearby.

In January 2007, sweetpotatoes were purchased from a roadside stall at Lembang in Java and at an open farmers' market at Hilo on the Island of Hawaii. In Java, as sweetpotatoes were uncommon in the markets at this time, only one whiteskinned cultivar, Ubi Kayu, was available. The three cultivars from Hawaii were distinguished by the color and shape of the storage roots (Table 1).

Storage roots or cuttings of the sweetpotatoes collected at the above locations were

Table 1. Isolates of Sweet potato virus G (SPVG) characterized in this study and the publicly available sequences of SPVG

\begin{tabular}{lllll}
\hline Isolate & Origin and sampling year & Cultivar $^{\mathbf{a}}$ & Accession no. & Reference \\
\hline 3817 & Toahotu, Tahiti, 2004 & $-(\mathrm{PS})$ & EU220757 & This study \\
3900A & Mataura, Tubuai, 2004 & $-(\mathrm{PS})$ & EU220759 & This study \\
CTB3 & Capetown, South Africa, 2005 & Borie & EU220756 & This study \\
HAWA2 & Hilo, Hawaii, 2007 & $-($ WF, PS, IS) & EU220753 & This study \\
HAWB3 & Hilo, Hawaii, 2007 & -(OF, PS, OS) & - & This study \\
HAWC4 & Hilo, Hawaii, 2007 & -(WF, WS, ES) & - & This study \\
JAAC & Lembang, Java, 2007 & Ubi Kayu & EU220755 & This study \\
NZ-4 & Dargaville, New Zealand, 2004 & Owairaka Red & EU220758 & This study \\
PS1B & Hanga Roa, Easter Island, 2005 & Tukuhamei & EU220754 & This study \\
SP1, SP2 & Dargaville (New Zealand) via post- & Owairaka Red & EF514221 & This study \\
& entry quarantine in W-Australia, & & & \\
ZIMB1C & 2005 & & & \\
ZIMB1H & Victoria Falls, Zimbabwe, 2005 & Chena & EU220752 & This study \\
Ark15 & Victoria Falls, Zimbabwe, 2005 & Chena & EU220751 & This study \\
Henan & Areka, Ethiopia & Gadissa & Not available & $(1)$ \\
Hua2 & Henan, China & Unknown & DQ399861 & - \\
Sichuan1 & Huaral, Peru & Unknown & EU218528 & $(40)$ \\
& Sichuan, China & Xushu \#18 & EU218531, & - \\
Sichuan2 & Sichuan, China & & EU218532 & \\
LSU-3 & Louisiana, USA & Sankang \#1 & EU216733 & $(19)$ \\
LSU-1 & Louisiana, USA & Unknown & AY178990 & $(36)$ \\
SPVG-CH & Guangdong, China & Unknown & AY178991 & $(36)$ \\
SPVG-CH2 & Guangdong, China & Unknown & X76944 & $(11)$ \\
SPVG-Eg & Egypt & Unknown & Z83314 & $(12)$ \\
SPVGMal02 & Spain & Abees & AJ515380 & $(21)$ \\
SPVG181-3Can07 & Spain & Unknown & EF577438 & - \\
\hline
\end{tabular}

${ }^{a}$ Cultivar if known, and characteristics of storage roots for unknown cultivars: ES, elongated shape; IS, irregular shape; OF, orange flesh; OS, oval shape; PS, purple skin; WF, white flesh; WS, white skin.

${ }^{b}$ The characterized 3'-proximal part of the viral sequence of the isolate was identical to HAWA2.

${ }^{c}$ Sequences of the isolates from the two plants SP1 and SP2 of the same cultivar were characterized and found to be identical. sent to the University of Helsinki, Finland, where they were planted and grown in an insect-proof greenhouse under the conditions stipulated in the import permit provided by the Finnish plant quarantine authorities. Plants of the indicator host $I$. setosa were grown from seed. Plants were grown in natural daylight under a 16-h photoperiod (light intensity $250 \mu \mathrm{E} \cdot \mathrm{s}^{-1} \cdot \mathrm{m}^{-1}$ ) extended and supplemented when needed with illumination from high pressure sodium lamps (OSRAM E40/ES, 400W) at a temperature of $20 / 24^{\circ} \mathrm{C}$ (night/day). The only exception to this was a storage root of cv. Owairaka Red sent from New Zealand to Perth, Western Australia in March 2005. This was grown in a post-entry quarantine glasshouse at South Perth, where eight cuttings propagated from it were each grafted with I. setosa scions.

Virus testing. S. Fuentes and L. F. Salazar (International Potato Center - CIP, Lima, Peru) and J. Vetten (Institute for Plant Virology, Braunschweig, Germany) kindly supplied virus-specific polyclonal and monoclonal antibodies, and enzyme conjugates to SPVG, SPFMV, and Sweet potato chlorotic stunt virus (SPCSV; genus Crinivirus, family Closteroviridae) for use in nitrocellulose membrane enzyme-linked immunosorbent assay (NCM-ELISA), double antibody sandwich (DAS) or triple antibody sandwich (TAS) ELISA. Previously described procedures were followed to test samples of sweetpotato or I. setosa leaf tissue by NCM-ELISA (17) or DASELISA and TAS-ELISA in microtiter plates (37). For testing I. setosa tissue extracts in Australia for SPVG, SPFMV, SPCSV, and six other viruses that infect sweetpotato, polyclonal and monoclonal antibodies were used in DAS-ELISA and TAS-ELISA, respectively. The test procedures followed for the viruses were as described by Tairo et al. (37). The NCM strips spotted with sap from virus-positive and noninfected control plants were supplied by CIP and used to interpret the results of NCM-ELISA. For the microtiter plate ELISAs, absorbance values were recorded at $405 \mathrm{~nm}\left(A_{405 \mathrm{~nm}}\right)$, and readings at least three times the values of the negative control samples were considered positive.

Owing to relatively high levels of resistance to potyvirus accumulation in many sweetpotato cultivars, virus titers are often low and direct virus detection from sweetpotato may be unreliable using serological tests. Therefore, grafting with $I$. setosa, a nearly universal host for sweetpotato viruses (7), is used to boost virus titers, and leaves of the grafted I. setosa are tested for viruses. In addition, graft-inoculation with SPCSV can be used to boost the titers of potyviruses $(24,25)$, including SPVG (26), in sweetpotato plants. Therefore, a few sweetpotato plants were graft-inoculated with SPCSV-Ug $(13,27)$ to increase the possibility of detecting SPVG by serological tests. 
RNA extraction, cDNA synthesis, and PCR amplification. Molecular characterization of the SPVG isolates was done in Finland unless indicated otherwise. For reverse transcription-polymerase chain reaction (RT-PCR) analysis, leaf samples $(0.5 \mathrm{~g})$ were frozen in liquid nitrogen and ground with mortar and pestle. Total RNA was extracted using a Trizol-like reagent (8). RNA was diluted to $200 \mu \mathrm{l}$ with nuclease free water (Sigma-Aldrich, St. Louis, MO, USA) and quantified with a spectrophotometer (Agilent 8452 A, Agilent Technologies). The cDNA synthesis was carried out in a $25-\mu$ l volume with $3 \mu \mathrm{g}$ of total RNA, polyT(25) primer, and Moloney murine leukemia virus (MMLV) reverse transcriptase (Promega, Madison, WI, USA) according to the manufacturer's instructions. The cDNA was diluted 1:10 and used as a template in PCR amplification.

Primers SPVG1-F (5'-TATACCGCGG AAAAGCACCCTACATAGCT-3') and SPVG3-R (5'-TATATGAGCTCCACTGA AGGCGAAACTGAAA-3') were designed according to the SPVG sequences available from databases. The primers included restriction sites for SacII and SacI, respectively, for cloning purposes (underlined). The amplified fragment of 1,285 nucleotides (nt), including primer sequences, consisted of $161 \mathrm{nt}$ of the replicase (NIb) encoding region, the entire coat protein (CP) encoding region (1,068 nt), and $51 \mathrm{nt}$ of the $3^{\prime}$-nontranslated ( $\left.3^{\prime} \mathrm{NTR}\right)$ region.

The PCR $(25 \mu \mathrm{l})$ consisted of $5 \mu \mathrm{l}$ of $5 \times$ Phusion GC Reaction buffer (containing $7.5 \mathrm{mM} \mathrm{MgCl}$ ), $0.5 \mu \mathrm{l}$ of $50 \mathrm{mM} \mathrm{MgCl}$, $0.5 \mu \mathrm{l}$ of $10 \mathrm{mM}$ dNTPs, $2 \mu \mathrm{l}$ of $10 \mu \mathrm{M}$ primers, $0.25 \mu \mathrm{l}(0.5 \mathrm{U})$ Phusion highfidelity DNA polymerase (Finnzymes, Espoo, Finland), and $2.5 \mu \mathrm{l}$ of cDNA. The cycling parameters were: 1 cycle at $98^{\circ} \mathrm{C}$ for $1 \mathrm{~min}$, followed by 40 cycles of $98^{\circ} \mathrm{C}$ for $10 \mathrm{~s}, 63^{\circ} \mathrm{C}$ for $20 \mathrm{~s}$, and $72^{\circ} \mathrm{C}$ for $45 \mathrm{~s}$, followed by a final extension at $72^{\circ} \mathrm{C}$ for $10 \mathrm{~min}$. Amplification products were analyzed by agarose gel electrophoresis and visualized under UV-light.

In Australia, symptomatic leaf tissue of I. setosa was ground to a fine powder under liquid nitrogen and the RNA extracted with an RNeasy Plant Mini kit (Qiagen, Doncaster, Victoria, Australia) according to the manufacturer's instructions. The entire SPVG CP-encoding region was amplified by RT-PCR using two pairs of primers that generate overlapping products. The forward primer PMB-9 (5'GGAACTATCAGAGTATGCACGAG-3') and the reverse primer PMB-10 (5'GTTCCATTCTCGATGCAC-3') amplify a 719-nt fragment from the $5^{\prime}$-proximal part, whereas primers PMB-11 (5'-GCACCA ATGGCAAATGGAAG-3') and PMB-12 (5'-ACACTGAAGGCGAAACTG-3') amplify a 688 -nt region from the $3^{\prime}$-proximal part of the CP-encoding sequence. RTPCR was carried out using the GeneAmp
RNA PCR kit (Applied Biosystems, Scoresby, Australia) as suggested by the manufacturer. The RT reaction mixture had a final volume of $10 \mu \mathrm{l}$ and contained 10 pmol of reverse primer (PMB-10 or PMB-12) and $1 \mu \mathrm{l}$ of RNA extract. The reaction was incubated at $42^{\circ} \mathrm{C}$ for 30 min, followed by $96^{\circ} \mathrm{C}$ for $5 \mathrm{~min}$. For $\mathrm{PCR}$, the volume of the reaction mixture was increased to $50 \mu \mathrm{l}$, and $10 \mathrm{pmol}$ of forward primer (PMB-9 or PMB-11) was added. PCR cycling involved one cycle of initial denaturation at $94^{\circ} \mathrm{C}$ for $3 \mathrm{~min}$, followed by 30 cycles of $94^{\circ} \mathrm{C}$ for $30 \mathrm{~s}$, $55^{\circ} \mathrm{C}$ for $30 \mathrm{~s}$, and $72^{\circ} \mathrm{C}$ for $60 \mathrm{~s}$, with a final extension at $72^{\circ} \mathrm{C}$ for $7 \mathrm{~min}$. PCR products were purified using a Qiagen PCR Purification kit (Qiagen, Doncaster, Victoria, Australia) following the manufacturer's instructions.

Cloning, sequencing, and sequence analysis. In Finland, the PCR amplification products were purified either with isopropanol precipitation or from the gel using a Gel Extraction Kit (Omega BioTek, Lilburn, GA, USA). Prior to ligation, an A-tailing reaction was carried out with the PCR products. The reaction $(10 \mu \mathrm{l})$ contained $1 \mu \mathrm{l}$ of $10 \mathrm{mM}$ dATP, $1 \mu \mathrm{l}$ of $10 \times$ optimized DyNAzyme PCR buffer (containing $\mathrm{MgCl}_{2}$ ), and $1 \mathrm{U}$ of DyNAzyme II DNA polymerase (Finnzymes). The reaction was carried out at $70^{\circ} \mathrm{C}$ for $30 \mathrm{~min}$ and terminated by transferring the tube to ice. Subsequently, PCR products were ligated to the pGEM-T or pGEM-T Easy Vector (Promega) according to manufacturer's instructions and cloned in Escherichia coli (strain DH5 $\alpha$ ). The plasmids were purified from E. coli with GenElute Plasmid Miniprep Kit (Sigma-Aldrich) and sequenced first using M13 primers (Promega) and subsequently nested primers designed according to the viral sequences. Both strands of at least two independent cDNA clones from each SPVG isolate were sequenced. All sequencing was done with Applied Biosystems Dye Terminator (v.3.1) sequencing kit and a capillary sequence analyzer at the Haartman Institute, Sequencing Core Facility, University of Helsinki.

In Australia, RT-PCR products were sequenced directly from both strands in an ABI 3730 DNA Analyzer using BigDye v. 3.1 Terminator chemistry (Applied Biosystems). Raw sequence data were edited with Sequence Scanner V. 1 (Applied Biosystems) and the overlapping fragments concatenated using BioEdit version 5.0.6. (provided by T. Hall, Department of Microbiology, North Carolina State University, Raleigh, USA). Sequence alignments and phylogenetic analysis using the neighbor-joining method were done using the MEGA program (version 3.1) (28). The "showaling" function of EMBOSS (The Finnish IT Center for Science, Espoo, Finland) was used to display the multiple amino acid sequence alignments.
Additional verification of the sequences. The sequence data were verified by additional analyses to confirm that they were accurate and not an artifact arising from PCR, sequencing errors, contamination of samples, or other technical errors. Therefore, in addition to primers designed from SPVG sequences, the samples were also tested with a forward degenerate primer (PVD-2) complementary to the nucleotide sequence coding for the conserved GNNSGQ motif in the NIb region of the Potyviridae (18) and the reverse primer $(10820 \mathrm{R})$ complementary to the $3^{\prime}$ end of the $3^{\prime}$ NTR of viruses of the genus Potyvirus (39) and which amplify many different potyviruses.

The storage roots from Hawaii and Java were collected 2 years after the other samples, planted in a different greenhouse compartment, and grown in isolation to obtain small shoots and leaves. They were not handled before taking leaf samples for RNA extraction and RT-PCR analysis. The PCR products were cloned and sequenced, as with all previously characterized SPVG isolates. Subsequently, all reagents needed for the work were replaced with fresh stocks; new leaf samples were taken from the same plants; but this time, the PCR products were sequenced directly (without cloning). RNA was also extracted again from stored, frozen leaves of the plants NZ-4 from New Zealand and CTB3 from South Africa, analyzed by RT-PCR, and the PCR products subjected to direct sequencing.

\section{RESULTS}

Detection of SPVG in sweetpotatoes. When grown in the greenhouse in Finland, no apparent symptoms developed in the shoots of the sweetpotatoes from Tahiti, whereas the plants from Tubuai displayed vein clearing and chlorotic spots on leaves. SPVG was not detected in these plants by repeated tests using NCM-ELISA (data not presented), whereas the plants from both sources were positive for SPVG when tested by RT-PCR. However, when the plants were graft-inoculated with SPCSV, the increased titers of SPVG became detectable by NCM-ELISA in the sweetpotato plants from Tahiti but not from Tubuai. All plants were SPFMV-positive when tested by NCM-ELISA (data not shown). The CP-encoding region of SPVG was amplified, cloned, and the sequences characterized for SPVG isolates from one plant of each landrace (3817 from Tahiti and 3900A from Tubuai) (Tables 1 and 2).

The plants grown from storage roots obtained from Easter Island showed no symptoms, but RT-PCR detected SPVG in the leaves of the red-skinned cultivar $\mathrm{Tu}$ kuhamei (Table 1). The CP-encoding sequence of this isolate (PS1B) was cloned and sequenced.

All plants grown from cuttings from eight sweetpotato cultivars or landraces 
from New Zealand tested negative for SPVG in NCM-ELISA, but NCM-ELISA detected SPVG (isolate NZ-4) in scions of I. setosa grafted onto vines of one plant of cv. Owairaka Red (Table 1), and this isolate was characterized.

In Australia, DAS-ELISA detected SPVG in I. setosa scions grafted on two of the eight cv. Owairaka Red plants growing in post-entry quarantine, whereas all eight plants were infected with SPFMV (data not presented). The $\mathrm{CP}$-encoding region of the two SPVG isolates (SP1 and SP2) (Table 1) was characterized independently in Australia and Finland.

The shoots of the sweetpotatoes from Java and Hawaii grew without symptoms. However, RT-PCR detected SPVG in all plants. The CP-encoding sequence was characterized from isolate JAAC from Java and isolates HAWA2, HAWB3, and HAWC4 from one plant of each of the three cultivars from Hawaii (Table 1).

SPVG (isolate CTB3) was detected by DAS-ELISA in the shoots of cv. Borie sampled in Capetown, South Africa (data not presented). The $\mathrm{CP}$-encoding region was amplified and sequenced from one plant (Table 1). RT-PCR detected SPVG in leaves of the plant grown from the tuber of cv. Chena obtained from a field close to Victoria Falls Airport, Zimbabwe (Table
1). The $\mathrm{CP}$ sequences of two isolates (Zimb1C, Zimb1H) were characterized from this plant.

Comparison of CP-encoding sequences. The $\mathrm{CP}$-encoding sequences of isolates HAWA2, HAWB3, and HAWC4, characterized from single plants of three different cultivars from Hawaii, were identical. These cultivars were purchased from the same farmers' stall, so they possibly came from the same field. HAWA2 was chosen as the representative sequence (Tables 2 and 3). The sequences of isolates SP1, HAWA2, 3900A, CTB3, and Zimb1H from New Zealand, Hawaii, Tubuai, South Africa, and Zimbabwe, respectively, were identical (Table 2) despite their very distant geographical origins and the different years of sampling and analysis. Isolates JAAC from Java and NZ-4 from New Zealand differed from these isolates only at one and two nucleotide positions, respectively, differences which were predicted to result in a single amino acid substitution in both isolates (Table 2). The three isolates Zimb1C, 3817, and PS1B from Zimbabwe, Tahiti, and Easter Island, respectively, also were identical to one another. These three isolates differed from the others at seven positions, of which two were predicted to cause an amino acid substitution (Table 2). At the same time, analysis of the CP- encoding region revealed that the plant from Zimbabwe was co-infected with two clearly different SPVG isolates, ZIMB1C and ZIMB1H (Table 2). Additional clones were amplified and sequenced, which confirmed the result (data not shown). All sequences characterized in this study differed from the previously characterized $\mathrm{CP}$-encoding sequences of isolates Henan, Sichuan1, SPVG-CH, and SPVG-CH2 from China, isolate SPVG-Eg from Egypt, Ark15 from Ethiopia, Hua2 from Peru, and two identical isolates (LSU-1 and LSU-3) from the United States (Tables 1 and 2).

Nucleotide identity of the CP-encoding region $(1,068 \mathrm{nt})$ of the SPVG isolates characterized in this study and those of seven isolates reported in previous studies was 85 to $100 \%$, excluding the partial sequences of the two isolates LSU-1 and LSU-3 from the United States. The corresponding $\mathrm{CP}$ amino acid (aa) sequences were 94 to $100 \%$ identical. When sequences of $612 \mathrm{nt}$ corresponding to the $\mathrm{N}$ proximal part of the $\mathrm{CP}$ of the two isolates from the United States were included in comparisons, nucleotide and amino acid identities were 79 to $100 \%$ and 89 to $100 \%$, respectively. On the other hand, when the most different Chinese isolate $\mathrm{CH} 2$ and Peruvian isolate Hua2 were excluded from comparisons, nucleotide and

Table 2. Variable nucleotide positions in the coat protein (CP) encoding region of 19 Sweet potato virus $G$ (SPVG) isolates

Nucleotide position $^{\mathrm{a}}$

$\begin{array}{lllllllllllllllllllllllllllllllllllllllll}1 & 1 & 1 & 1 & 1 & 1 & 2 & 2 & 2 & 2 & 2 & 3 & 3 & 3 & 3 & 3 & 3 & 3 & 3 & 3 & 3 & 3 & 3 & 3 & 3 & 4 & 4 & 4 & 4 & 4 & 4 & 6 & 6 & 6 & 6 & 8 & 8 & 8 & 8 & 8 & 0\end{array}$

$\begin{array}{llllllllllllllllllllllllllllllllllllllllllllllll}1 & 1 & 1 & 2 & 3 & 8 & 1 & 2 & 5 & 7 & 8 & 8 & 0 & 1 & 2 & 6 & 8 & 0 & 0 & 0 & 0 & 4 & 4 & 4 & 4 & 5 & 5 & 6 & 8 & 8 & 9 & 0 & 2 & 5 & 7 & 8 & 9 & 0 & 2 & 3 & 3 & 0 & 1 & 3 & 4 & 5 & 0\end{array}$

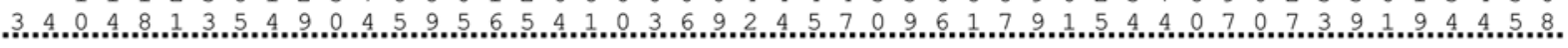

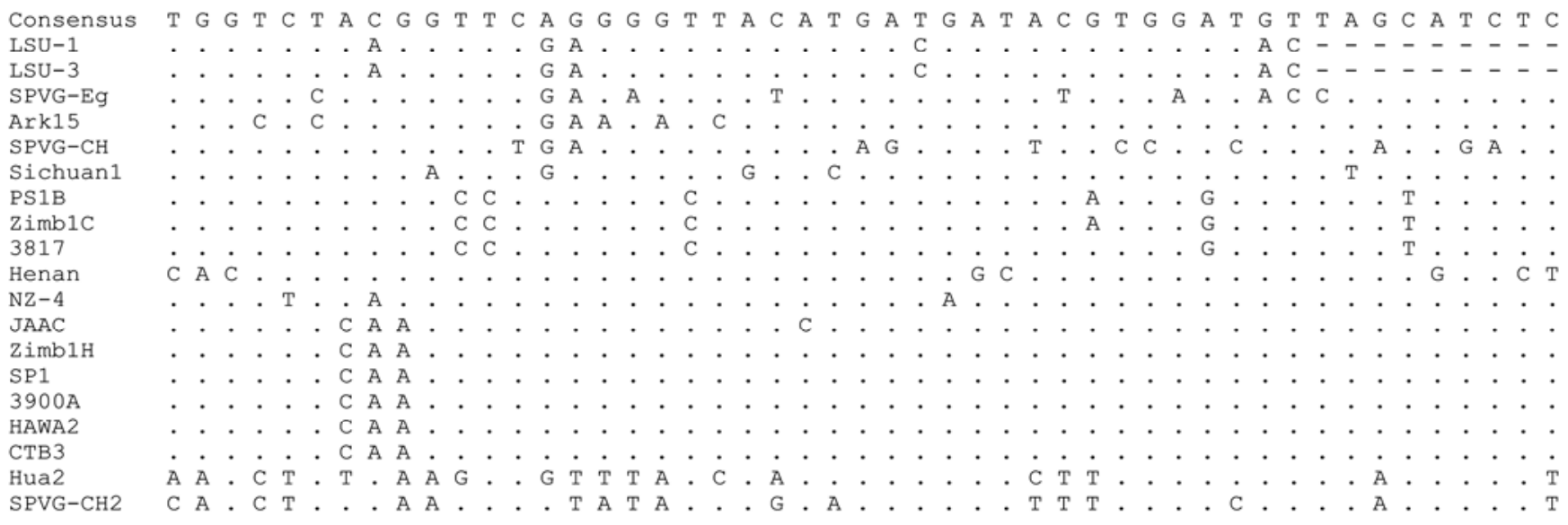

Amino acid $S$ A E I Y D T T L Q G I P Q A L A G I G R D Q T G G V R D N G F R L R V T Y S $N$ N T P Y L T L A H

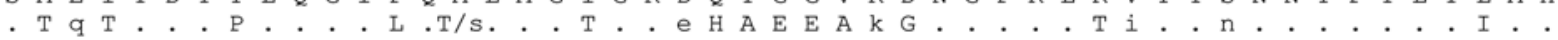

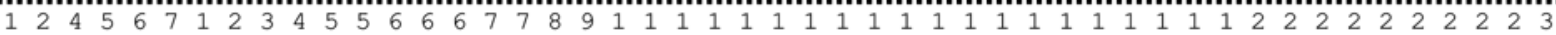
$\begin{array}{llllllllllllllllllllllllllllllllllllllllllll}1 & 9 & 8 & 5 & 0 & 8 & 2 & 3 & 9 & 2 & 5 & 8 & 4 & 0 & 0 & 0 & 0 & 1 & 1 & 1 & 1 & 1 & 2 & 2 & 2 & 2 & 3 & 3 & 4 & 5 & 5 & 6 & 6 & 0 & 0 & 1 & 1 & 6 & 7 & 7 & 8 & 8 & 3\end{array}$ $\begin{array}{llllllllllllllllllllllllllllll}0 & 1 & 2 & 3 & 4 & 5 & 5 & 6 & 7 & 0 & 2 & 7 & 9 & 3 & 4 & 2 & 2 & 8 & 0 & 6 & 0 & 9 & 1 & 3 & 7 & 3 & 8 & 2 & 5 & 6\end{array}$

\footnotetext{
${ }^{a}$ Numbers vertically positioned above and below the sequence alignment indicate positions of the SPVG CP nucleotides and amino acid residues shown, respectively, according to the majority of isolates. Bases that are different from the consensus are indicated, whereas bases identical to consensus are marked with dots. Amino acid residues that are not identical to consensus predictions owing to nucleotide substitutions in some isolates are at the bottom. Chemically similar residues are marked with lowercase letters, whereas different residues are marked with uppercase letters. Identical amino acids are indicated by dots. Position 69 contains an alanine (A), threonine (T), or serine (S) residue depending on the isolate. The sequences of isolates SPVG-CH2 from China and Hua2 from Peru are exceptional in that they contain differences also in other sequence areas that are not shown. Isolate Hua2 contains an insertion (TACAAA) at position 316-321 and isolate Ark15 at position 528-530, which should be considered in the numbering of nucleotides and amino acids after these positions in these two isolates.
} 
amino acid identities were 97 to $100 \%$ and 96 to $100 \%$, respectively. In these comparisons, the putative frameshift in the $\mathrm{CP}$ encoding region of Ark15, starting from nucleotide 506 (base deletion) to 534 (base insertion), was ignored because it was suspected to be a sequencing error. When the respective base deletion and insertion were ignored, the putative frameshifted region of Ark15 was identical to those of several SPVG isolates (data not shown). Isolate Ark15 had an insertion of $3 \mathrm{nt}$ (CAA) at position 528-530, whereas isolate Hua2 had a 6-nt insertion (TACAAA) at position 316-321, as compared to the other isolates of SPVG.

The CP-encoding region of the Chinese isolate Sichuan 2 has been partially characterized for a relatively conserved 665-nt central portion that corresponds to the aa 109-325 in isolate Sichuan1 for which the complete CP sequence is available (Table $1)$. This part of the CP-encoding region showed only $88 \%$ nucleotide and $95 \%$ amino acid identity between these two isolates. Comparison of this 655-nt region in all five Chinese isolates (Henan, Sichuan1, Sichuan2, SPVG-CH, SPVG-CH2) revealed 86 to $99 \%$ and 94 to $99 \%$ identity at the nucleotide and amino acid levels, respectively (Table 3). These are the most divergent SPVG sequences compared.

Two recently deposited partial sequences (434 nt) of the CP-encoding region from two SPVG isolates detected in Spain (SPVGMa102 and SPVG1813Can07) were available in GenBank (Table 1). These sequences began at the $\mathrm{CP}$ nucleotide position 269 and when compared to other SPVG CP nucleotide sequences (excluding the most different Chinese and Peruvian isolates), they were 98 to $100 \%$ identical (data not shown).

Phylogenetic analysis of SPVG CPencoding sequences. To include the partial
$\mathrm{CP}$-encoding sequences of the two isolates from the United States, phylogenetic analysis was carried out on only the $\mathrm{N}$ proximal $612 \mathrm{nt}$ of the $\mathrm{CP}$-encoding sequences to determine whether the SPVG isolates belonged to different genetic lineages (Fig. 1A). Neighbor-joining analysis indicated that isolates SP1, JAAC, HAWA2, 3900A, CTB3, and Zimb1H formed one group, whereas the isolates Zimb1C, 3817, and PS1B formed another group (Fig. 1A). The two U.S. isolates differed from the Egyptian isolate $\mathrm{Eg}$ by only two nucleotides and formed a third cluster. The Chinese isolates $\mathrm{CH}$ and $\mathrm{Si}$ chuan 1 and the Ethiopian isolate Ark15 were very closely related to each other, as were the isolates Henan and NZ-4 from China and New Zealand, respectively. The Chinese isolate SPVG-CH2 and the Peruvian isolate Hua2 formed a cluster distinct from all others (Fig. 1).

Phylogenetic analysis was also done using the central part (665 nt) available from isolate Sichuan2 and the corresponding part of all other isolates except those from the United States and Spain. Results indicated that in the main cluster including all but three SPVG isolates, the isolates Zimb1C, 3817, and PS1B formed, again, a cluster of their own, and also that Eg was distinguished from the others (Fig. 1B). Sichuan2, Hua2, and $\mathrm{CH} 2$ and all the other isolates represented four distinguishable genetic lineages or strains, respectively (Fig. 1B).

Additional verification of the sequences. Samples that were positive for SPVG when tested with the primers designed for SPVG were also positive when degenerate primers PVD-2 and 10820R that detect many different potyviruses were used. Amplification products were of the expected size, and the $\mathrm{CP}$ sequences of products obtained with both PCRs were identical (data not shown). Also, the CPencoding regions of isolates SP1 and SP2 from New Zealand (detected in post-entry quarantine in Perth, Australia) were cloned and sequenced independently in Finland and Australia, with identical sequence results in the two laboratories (data not shown). The CP-encoding sequences of the SPVG isolates from Hawaii, Java, and New Zealand were determined twice. The first time, the amplification products were cloned and sequenced, whereas the second time they were sequenced directly without cloning. Results from both analyses were identical (data not shown). These data show that the sequences of different isolates were genuine and not due to PCR or sequencing errors. One factor possibly contributing to accuracy in sequence analyses was the use of the DNA polymerase Phusion, which shows a 25 -fold higher fidelity than the Taq DNA polymerase (6).

\section{DISCUSSION}

The results from this study together with those of other authors indicate that SPVG occurs in most sweetpotato production areas worldwide. Here, SPVG was found for the first time in parts of greater Oceania that represent the geographical extremities of the region, including Java, New Zealand, Hawaii, French Polynesia (Tahiti and Tubuai), and Easter Island, and also in southern parts of Africa in Zimbabwe and South Africa. Previously, SPVG was found in eastern Asia in China $(11,12,19)$, northern Africa in Egypt (21), eastern Africa in Ethiopia (1), and North America in the southern United States (36). Recently, SPVG was also detected for the first time in South America in Peru (40) and in Europe in Spain (GenBank accession nos. EF577438 and EF577439).

Therefore, this virus is now known to exist

Table 3. Percent nucleotide (upper diagonal) and amino acid (lower diagonal) sequence identities of the central part of the coat protein (CP) encoding sequences of Sweet potato virus $G$ beginning from the nucleotide and amino acid positions 320 and 109, respectively

\begin{tabular}{|c|c|c|c|c|c|c|c|c|c|c|c|c|c|c|c|c|c|c|c|c|c|}
\hline & Isolate & Origin & 1 & 2 & 3 & 4 & 5 & 6 & 7 & 8 & 9 & 10 & 11 & 12 & 13 & 14 & 15 & 16 & 17 & 18 & 19 \\
\hline 1 & SPVG-Eg & Egypt & $* * *$ & 99 & 97 & 9 & 98 & 98 & 98 & 98 & 99 & 99 & 99 & 99 & 99 & 99 & 99 & 88 & 86 & 86 & 80 \\
\hline 2 & Ark15a & hiopi & 99 & $* * *$ & 98 & 99 & 99 & 99 & $O c_{2}>$ & 99 & 99 & 99 & 99 & 99 & 9 & 99 & 99 & 89 & 87 & 86 & 79 \\
\hline 3 & SPVG-Cl & China & 97 & 98 & $* * *$ & 98 & 98 & 98 & & 98 & 98 & 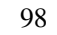 & 9 & 98 & 8 & 98 & 98 & 87 & & 86 & 79 \\
\hline 4 & Sichuan1 & China & 99 & 100 & 98 & $* * *$ & 99 & 95 & 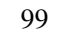 & 99 & 99 & 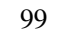 & 0 & 99 & 00 & & 99 & 88 & & 86 & 79 \\
\hline 5 & PS1B & Easter Island & 99 & 100 & 98 & 100 & $* * *$ & 100 & , & 98 & 99 & 9 & 9 & 99 & & 0 & 99 & 0 & 7 & 86 & 80 \\
\hline 6 & Zimb1C & Zimbabwe & 99 & 100 & 98 & 100 & 100 & $* * *$ & 99 & 98 & 99 & 99 & 99 & 99 & $0 c>-$ & 90 & 99 & 9 & 87 & 86 & 80 \\
\hline 7 & 3817 & Tahit & 99 & 100 & 98 & 100 & 100 & 100 & $* * *$ & 99 & 99 & 99 & 95 & 99 & 94 & 0 & 99 & 8 & & 86 & 79 \\
\hline 8 & Henan & China & 9 & 99 & 97 & 99 & 99 & 99 & 99 & $* * *$ & 99 & 96 & 95 & 99 & 99 & 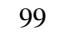 & 99 & 88 & & 6 & 79 \\
\hline 9 & NZ-4 & New $Z$ & 98 & 99 & 97 & 99 & 99 & 99 & 99 & 99 & $* * *$ & 99 & 99 & 99 & 99 & 99 & 99 & $\gamma$ & & 86 & 79 \\
\hline 10 & JAAC & Java & 99 & 100 & 98 & 100 & 100 & 100 & 100 & 100 & 99 & $* * *$ & 100 & 100 & 100 & 100 & 100 & 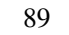 & 01 & 86 & 79 \\
\hline 11 & Zimb1H & Zimbabwe & 99 & 100 & 98 & 100 & 100 & 100 & 100 & 99 & 99 & 100 & $* * *$ & 100 & 100 & 100 & 100 & 89 & & 86 & 79 \\
\hline 12 & SP1 & & 0 & & & 100 & 10 & 10 & & 9 & 99 & 100 & 100 & $* * *$ & & & 0 & & & & 79 \\
\hline 13 & 3900 & & 9 & 10 & 98 & 10 & 10 & 10 & 100 & 9 & 99 & 100 & 100 & 100 & $* * *$ & 1 & 0 & & & 6 & 79 \\
\hline 14 & HAWA2 & $\mathrm{H}$ & 99 & 100 & 98 & 100 & 100 & 10 & 100 & 99 & 99 & 100 & 100 & 100 & 100 & $* * *$ & 100 & 89 & 0 & 86 & 79 \\
\hline 15 & CTB3 & South Africa & 99 & 100 & 98 & 100 & 100 & 100 & 100 & 99 & 99 & 100 & 100 & 100 & 100 & 100 & $* * *$ & 89 & 87 & 86 & 79 \\
\hline 16 & Sichuan2 & China & 94 & 95 & 94 & 95 & 95 & 95 & 95 & 95 & 95 & 95 & 95 & 95 & 95 & 95 & 95 & $* * *$ & 87 & 86 & 76 \\
\hline 17 & Hua2 & Peru & 95 & 9 & 94 & 96 & 96 & 96 & 96 & 9 & 96 & 9 & 9 & 9 & 9 & 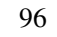 & 96 & 95 & $* * *$ & 87 & 77 \\
\hline 18 & SPVG-CH2 & China & 95 & 96 & 9 & 96 & 96 & 9 & 96 & 9 & 9 & 9 & 9 & 9 & 96 & $e^{2}>$ & 96 & 94 & 94 & $* * *$ & 77 \\
\hline 19 & SPV2 & & 88 & 87 & 86 & 87 & 87 & 87 & 87 & 87 & 87 & 87 & 87 & 87 & 87 & 87 & 87 & 87 & 85 & 86 & $* * *$ \\
\hline
\end{tabular}

${ }^{a}$ A putative frameshift in the CP-encoding region of Ark15 (nt 506-534) (1) was anticipated to be a sequencing error and was not taken into consideration in the deduced amino acid sequence. 

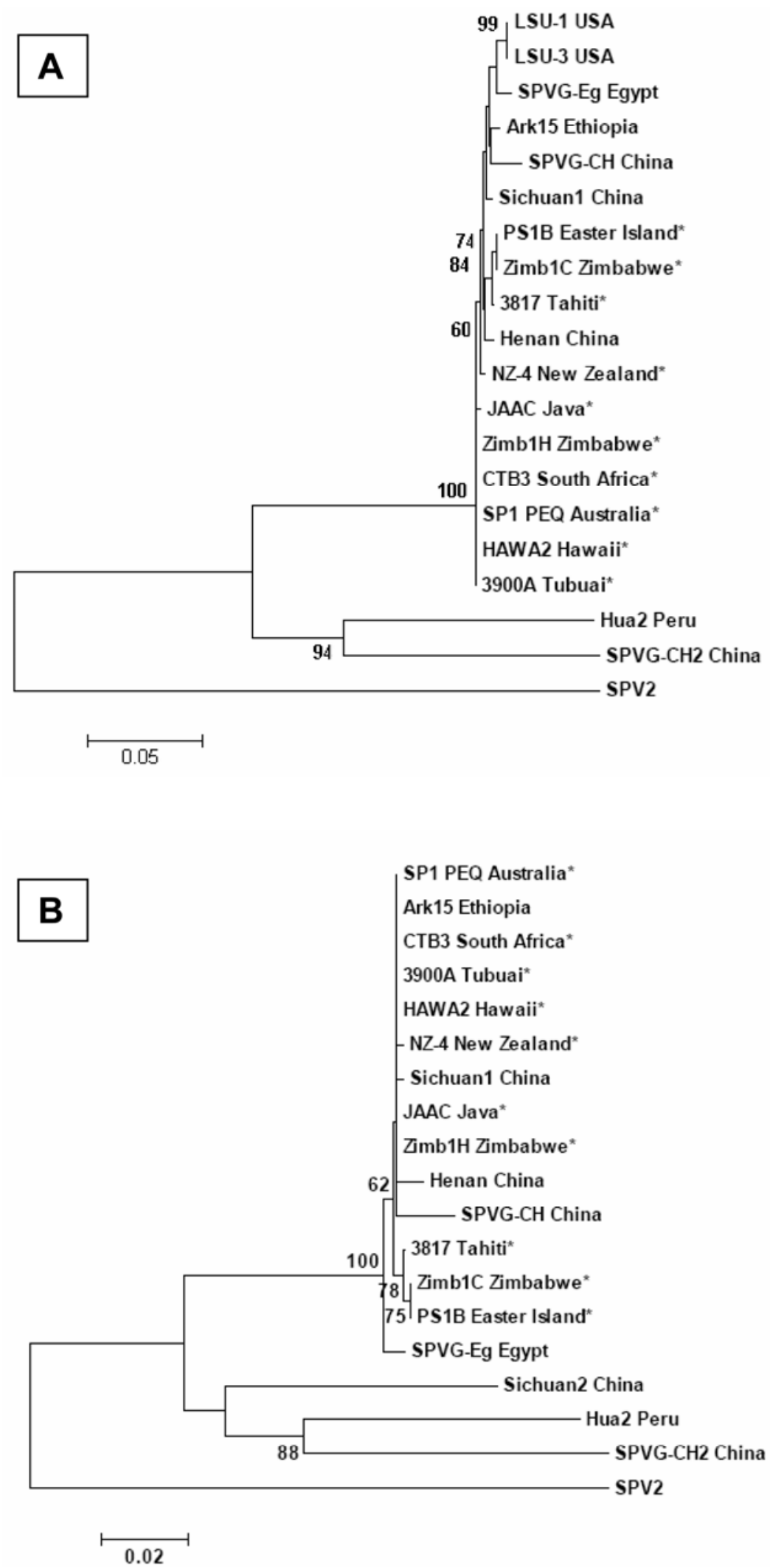

Fig. 1. Phylogenetic analysis of partial coat protein (CP) coding sequences of Sweet potato virus $G$ (SPVG) isolates. Isolates marked with an asterisk (*) were characterized in this study. A, Analysis of the N-proximal $612 \mathrm{nt}$ of 19 isolates. The C-proximal part was omitted because it is not available from the two American isolates (LSU-1 and LSU-3). B, Analysis of the central part (665 nt) of the CP encoding region starting from position 320, including the Chinese isolate Sichuan2, of which only the sequence of this region is available. Isolates LSU-1 and LSU-3 were excluded. The CP sequence of Sweet potato virus 2 (SPV2), isolate Aus55-4 (GenBank accession no. AM050885) was used as an outgroup. The bootstrap values exceeding $60 \%$ of 1,000 replicates are shown. Scale indicates the Kimura nucleotide distance (Knuc). in most regions of the world where sweetpotato is grown as a major crop for subsistence, as a cash crop, or for industrial purposes.

This study revealed the presence of a surprisingly homogenous global population of SPVG isolates. The exceptions were two isolates from China (SPVG-CH) (12) and the Peruvian isolate Hua2 (40), which each differ clearly from all others. Considering the length of time sweetpotato has been distributed around the world and the separate distribution routes it has taken, this result was unexpected and is intriguing, as much greater sequence divergence might have been expected. Currently, it appears that two isolates from China, one isolate from Peru, and all the rest represent four distinct genetic lineages of SPVG. Studies of genetic diversity in populations of the two other sweetpotato-infecting potyviruses, SPV2 and SPFMV, for which a similar or larger number of isolates has been characterized, revealed a similar picture. In SPV2, genetic diversity of the CPencoding sequences is within the range of that for SPVG, and SPV2 isolates form at least three distinct phylogenetic groups (37). However, data are insufficient to conclude whether any strain of SPV2 shows a worldwide distribution similar to that of SPVG. Isolates of SPFMV can be placed into four phylogenetic groups, of which one (EA) is largely but not entirely restricted geographically to East Africa (39). Isolates belonging to the other groups are distributed worldwide (39). The CPencoding region of strain $\mathrm{C}$ of SPFMV is phylogenetically distant from the other three strains which are closely related and, additionally, contains a 6-nt deletion (39). Data from this study indicated that the $\mathrm{CP}$ in isolates of SPVG can have at least three lengths due to insertion of one (Ark15) or two codons (Hua2), as compared to other isolates.

Sequence differences between the Chinese and Peruvian SPVG isolates show that considerable sequence divergence exists, and yet, there was relatively little evidence of this in isolates collected from the rest of the world. The limited sequence divergence of isolates characterized in this study suggests the same SPVG strain consisting of minor sequence variants (i.e., a viral quasispecies) (14) was spread widely via exchange of sweetpotato germplasm, by plant breeding activities, or through the international trade of sweetpotatoes for use as a staple food. It seems noteworthy that in this study, sweetpotatoes purchased from farmers' markets in several countries in distant locations were found to be SPVG infected. Sweetpotatoes maintain viability during long-distance transport (as observed in this study), and can produce SPVG-infected foliage acting as a source of virus in the new geographic location. Hence, increased global movement of plant materials may have resulted in in- 
creased dispersal of a homogenous SPVG population around the world. Alternatively, SPVG might be unusually stable or the divergent strains less fit. Such possibilities cannot be excluded until more studies have been undertaken with SPVG.

An interesting task for future studies would be to determine the center of diversity and evolutionary dispersal of SPVG. At present, significant genetic variability of SPVG is known only in China. It may simply be that insufficient studies have been carried out elsewhere. On the other hand, it is intriguing that five isolates from China exhibit larger genetic variability than is found among 17 isolates characterized from all other continents. It is uncertain whether sweetpotato was introduced to China from the Philippines after Columbian times, or whether the Treasure Fleets of Cheng Ho (Zheng He) in 14051435 or previous voyages by other Chinese sailors to wide areas of the Pacific Ocean and the Caribbean over hundreds of years in the pre-Columbian times (31) introduced the new crop from these areas, where it was grown at that time (32). Taken together, it seems likely that movement of sweetpotatoes has occurred in the Pacific region for a long time $(10,32)$. Future studies will show whether SPVG originated in the center of origin of the crop in Mexico and Central America (42) or in China, as both seem possible in light of the current information.

This study indicated that SPVG may be difficult to detect in many sweetpotato cultivars or landraces because infected plants rarely display symptoms and virus titers are too low to be detected by serological tests. Graft-transmission of the virus from sweetpotatoes to I. setosa is therefore recommended to enhance SPVG titers to levels detectable by serological assays, preferably employing DAS- or TAS-ELISA. RT-PCR was found to be more sensitive than either but is not yet routinely used for sweetpotato virus diagnostics in most laboratories. In this study, SPVG was detected in cv. Owairaka Red from New Zealand in post-entry quarantine in Western Australia by indexing on $I$. setosa and by DAS-ELISA. SPVG and SPFMV co-infecting the plants were subsequently successfully eradicated by heat treatment and meristem tip culture. The original material was destroyed and a healthy clone released to the importer. Taken together, this suggests that symptomless infections could be a major problem that inadvertently enables the movement and distribution of SPVG from infected to uninfected regions. This is not a problem specific to SPVG, as in our experience other potyviruses such as SPFMV and SPV2 also often infect sweetpotato cultivars without apparent symptoms. For this reason, international quarantine measures for sweetpotatoes should be enhanced, and testing of imported germplasm, for all viruses of sweet potatoes, should become routine.

There is little data on the economical importance of SPVG. The lack of symptoms in SPVG-infected plants found in this study also was noted by others (26). In a previous study, SPVG or SPFMV alone caused no significant yield loss in sweetpotato cv. Beauregard, whereas coinfection with these two viruses reduced the yield by $14 \%$ (9). The yield effects of SPVG and also of many other potyviruses may have been overlooked in sweetpotatoes because SPFMV and its negative impacts dominate in all sweetpotato growing areas of the world $(23,39)$.

Co-infection of SPCSV with SPVG was observed to enhance SPVG titers and symptom severity in cv. Beauregard in a previous study (26). Elevated SPVG titers were also found in this study in landrace sweetpotato from French Polynesia experimentally co-infected with SPVG and SPCSV. In areas where both SPFMV and SPCSV occur, their co-infection causes the very severe sweetpotato virus disease (SPVD) (39), which again is likely to mask any effects of SPVG and lead to the general assumption that yield losses are solely caused by SPFMV and SPCSV. In conclusion, the incidence of SPVG in individual sweetpotato crops and the disease and growth effects it may have on different sweetpotato cultivars both warrant further investigation.

\section{ACKNOWLEDGMENTS}

We thank M. Calonius (Finland), E. Gajda, M. Kehoe, C. Wang, H. Wilson, and M. Holland (Australia) for skillful technical assistance; and the Australian Quarantine and Inspection Service for access to postentry quarantine facilities in Perth. Financial support from the Academy of Finland (grants 1102134 and 1110797) and the New Zealand Foundation for Research, Science and Technology is gratefully acknowledged.

\section{LITERATURE CITED}

1. Alemu, T. 2004. Characterisation of Viruses of Pepper (Capsicum spp.) and Sweet Potato (Ipomoea batatas) from Ethiopia. Ph.D. thesis. Rheinischen Friedrich-Wilhelms-Universität zu Bonn, Göttingen, Germany. (in German)

2. Anonymous. 2002. The identification, incidence and control of sweet potato viruses in East and South Africa. Annual Report 2002 of the project ICA4-1999-30048. National Resources Institute, Kent, UK.

3. Aritua, V., Bua, B., Barg, E., Vetten, H. J., Adipala, E., and Gibson, R. W. 2007. Incidence of five viruses infecting sweetpotatoes in Uganda; the first evidence of sweet potato caulimo-like virus in Africa. Plant Pathol. 56:324-331.

4. Ateka, E. M., Njeru, R. W., Kibaru, A. G., Kimenju, J. W., Barg, E., Gibson, R. W., and Vetten, H. J. 2004. Identification and distribution of viruses infecting sweet potato in Kenya. Ann. Appl. Biol. 144:371-379.

5. Atkey, P. T., and Brunt, A. A. 1987. Electron microscopy of an isometric caulimo-like virus from sweetpotato (Ipomoea batatas). J. Phytopathol. 118:370-376.

6. Balhoff, J. P., and Wray, G. A. 2005. Evolutionary analysis of the well characterized endo16 promoter reveals substantial variation within functional sites. Proc. Natl. Acad. Sci.
USA 102:8591-8596.

7. Brunt, A. A., Crabtree, K., and Gibbs, A. 1990 Viruses of Tropical Plants: Descriptions and Lists from the VIDE Database. C.A.B. International, UK.

8. Caldo, R. A., Nettleton, D., and Wise, R. P. 2004. Interaction-dependent gene expression in Mla specified response to barley powdery mildew. Plant Cell 16:2514-2528.

9. Clark, C. A., and Hoy, M. W. 2006. Effects of common viruses on yield and quality of Beauregard sweetpotato in Louisiana. Plant Dis. 90:83-88.

10. Clarke, W. C. 2007. The sweet potato in Oceania: A reappraisal. Contemporary Pacific 19:318-322.

11. Colinet, D., Kummert, J., and Lepoivre, P. 1994. The complete nucleotide sequences of the coat protein cistron and the $3^{\prime}$ non-coding region of a newly-identified potyvirus infecting sweet potato, as compared to those of sweet potato feathery mottle virus. Arch. Virol. 139:327-336.

12. Colinet, D., Nguyen, M., Kummert, J., Lepoivre, P., and Xia, F. Z. 1998. Differentiation among potyviruses infecting sweet potato based on genus- and virus-specific reverse transcription polymerase chain reaction. Plant Dis. 82:223-229.

13. Cuellar, W. J., Tairo, F., Kreuze, J. F., and Valkonen, J. P. T. 2008. Analysis of gene content in Sweet potato chlorotic stunt virus RNA1 reveals the presence of p22 RNA silencing suppressor in only a few isolates: Implications for viral evolution and synergism. J. Gen. Virol. 89:573-582.

14. Domingo, E., Baranowski, E., Ruiz-Jarabo, C. M., Martín-Hernández, A. M., Sáiz, J. C., and Escarmís, C. 1998. Quasispecies structure and persistence of RNA viruses. Emerging Inf. Dis. 4:521-527.

15. FAOSTAT. 2006. FAO Database. The Food and Agriculture Organisation of the United $\mathrm{Na}-$ tions, Rome, Italy.

16. Fletcher, J. D., Lewthwaite, S. L., Fletcher, P. J., and Dannock, J. 2000. Sweet potato (kumara) virus disease surveys in New Zealand. Pages 42-47 in: International Workshop on Sweetpotato Cultivar Decline Study. National Agricultural Research Center for Kyushu Okinawa Region, Miyajakonojo, Japan.

17. Gibb, K. S., and Padovan, A. C. 1993. Detection of sweet potato feathery mottle virus in sweet potato grown in Northern Australia using an efficient and simple assay. Intern. J. Pest Manag. 39:223-228.

18. Gibbs, A., and Mackenzie, A. 1997. A primer pair for amplifying part of the genome of all potyvirids by RT-PCR. J. Virol. Methods 63:916.

19. Gu, Y. H., Tang, H. R., and Zhang, Y. Z. 2006. Cloning and sequence analysis of sweet potato virus $\mathrm{G}$ coat protein gene. Chinese Agric. Sci. Bull. (Zhongguo Nong Xue Tong Bao) 22:5055.

20. Heisswolf, S., Galea, V. J., and Persley, D. M. 1994. A preliminary assessment of sweet potato cultivars for sweet potato feathery mottle virus (SPFMV). Aust. Plant Pathol. 23:77-80.

21. IsHak, J. A., Kreuze, J. F., Johansson, A., Mukasa, S. B., Tairo, F., Abo El-Abbas, F. M., and Valkonen, J. P. T. 2003. Some molecular characteristics of three viruses from SPVDaffected sweet potato plants in Egypt. Arch. Virol. 148:2449-2460.

22. Jones, R. A. C., and Dwyer, D. I. 2007. Detection of Sweet potato chlorotic fleck virus and Sweet potato feathery mottle virus - Strain O in Australia. Aust. Plant Pathol. 36:591-594.

23. Karyeija, R. F., Gibson, R. W., and Valkonen, J. P. T. 1998. The significance of sweet potato feathery mottle virus in subsistence sweet potato production in Africa. Plant Dis. 82:4-15.

24. Karyeija, R. F., Kreuze, J. F., Gibson, R. W., 
and Valkonen, J. P. T. 2000. Two serotypes of Sweetpotato feathery mottle virus in Uganda and their interaction with resistant sweetpotato cultivars. Phytopathology 90:1250-1255.

25. Karyeija, R. F., Kreuze, J. F., Gibson, R. W., and Valkonen, J. P. T. 2000. Synergistic interactions of a potyvirus and a phloem-limited crinivirus in sweet potato plants. Virology 269:26-36.

26. Kokkinos, C. D., and Clark, C. A. 2006. Interactions among Sweet potato chlorotic stunt virus and different potyviruses and potyvirus strains infecting sweetpotato in the United States. Plant Dis. 90:1347-1352.

27. Kreuze, J. F., Savenkov, E. I., and Valkonen, J. P. T. 2002. Analysis of the complete genomic sequence and subgenomic RNAs of Sweet potato chlorotic stunt virus reveals several new features for the genus Crinivirus. J. Virol. 76:9260-9270

28. Kumar, S., Tamura, K., and Nei, M. 2004. MEGA3: Integrated software for Molecular Evolutionary Genetics Analysis and sequence alignment. Briefings Bioinform. 5:150-163.

29. Lewthwaite, S. L. 1998. Commercial sweetpotato production in New Zealand: Foundations for the future. Pages 33-50 in: Proc. Int. Workshop Sweetpotato Production System Toward 21st Century. D. R. LaBonte, M. Yamashita, and H. Mochida, eds. Kyushu National Agricultural Experiment Station, Miyazaki, Miya- konojo, Japan

30. Loebenstein, G., Fuentes, S., Cohen, J., and Salazar, L. F. 2003. Sweet potato. Pages 223248 in: Viruses and Virus-Like Diseases of Major Crops in Developing Countries. G. Loebenstein and G. Thottapilly, eds. Kluwer Academic Publishers, Dortrecht, The Netherlands.

31. Menzies, G. 2002. 1421-The Year China Discovered the World. Bantam Books, Transworld Publishers, London, UK.

32. Montenegro, Á., Avis, C., and Weaver, A. 2007. Modeling the prehistoric arrival of the sweet potato in Polynesia. J. Archaeol. Sci. 35:355-367.

33. Mukasa, S. B., Rubaihayo, P. R., and Valkonen, J. P. T. 2003. Incidence of viruses and viruslike diseases of sweetpotato in Uganda. Plant Dis. 87:329-335.

34. Pearson, M. N., and Grisoni, M. 2002. Records of plant viruses for the Pacific Islands. Aust. Plant Pathol. 31:15-26.

35. Salazar, L. F., and Fuentes, S. 2000. Current knowledge on major virus diseases of sweet potatoes. Pages 14-19 in: Int. Workshop Sweetpotato Cultivar Decline Study. National Agricultural Research Center for Kyushu Okinawa Region, Miyajakonojo, Japan.

36. Souto, E. R., Sim, J., Chen, J., Valverde, R. A., and Clark, C. A. 2003. Properties of strains of Sweet potato feathery mottle virus and two newly recognized potyviruses infecting sweet potato in the United States. Plant Dis. 87:1226-1232

37. Tairo, F., Jones, R. A. C., and Valkonen, J. P. T 2006. Potyvirus complexes in sweetpotato: Occurrence in Australia, serological and molecular resolution, and analysis of the Sweet potato virus 2 (SPV2) component. Plant Dis. 90:1120-1128.

38. Tairo, F., Kullaya, A., and Valkonen, J. P. T. 2004. Incidence of viruses infecting sweetpotato in Tanzania. Plant Dis. 88:916-920.

39. Tairo, F., Mukasa, S. B., Jones, R. A. C., Kullaya, A., Rubaihayo, P. R., and Valkonen, J. P. T. 2005. Unraveling the genetic diversity of the three main viruses involved in Sweet Potato Virus Disease (SPVD) and its implications. Mol. Plant Pathol. 6:199-211.

40. Untiveros, M., Fuentes, S., and Kreuze, J. 2008. Molecular variability of sweet potato feathery mottle virus and other potyviruses infecting sweet potato in Peru. Arch. Virol. 153:473-483.

41. Untiveros, M., Fuentes, S., and Salazar, L. F 2007. Synergistic interaction of Sweet potato chlorotic stunt virus (Crinivirus) with carla-, cucumo-, ipomo-, and potyviruses infecting sweet potato. Plant Dis. 91:669-676.

42. Zhang, D. P., Rossel, G., Kriegner, A., and Hijmans, R. 2004. AFLP assessment of diversity in sweetpotato from Latin America and the Pacific region: Its implications of the dispersal of the crop. Genet. Res. Crop Evol. 51:115-120. 